\title{
No-choice ovipositional nonpreference of Bemisia tabaci (Gennadius) B biotype on tomato genotypes
}

\author{
Maria Auxiliadora de Godoy Oriani ${ }^{1}$ José Djair Vendramim²*; Cristina Jensen Vasconcelos ${ }^{1,3}$ \\ ${ }^{1}$ USP/ESALQ - Programa de Pós-Graduação em Entomologia, C.P. 9 - 13418-900 - Piracicaba, SP - Brasil. \\ ${ }_{3}^{2}$ USP/ESALQ - Depto. de Entomologia e Acarologia, C.P. 9 - 13418-900 - Piracicaba, SP - Brasil. \\ ${ }^{3}$ UNIMEP - Graduação em Ciências Biológicas, Rod. do Açúcar, km 156 - 13400-911 - Piracicaba, SP - Brasil. \\ *Corresponding author <jdvendra@esalq.usp.br>
}

\begin{abstract}
Brazil is one of the main tomato producers worldwide. Nevertheless, 40 to $70 \%$ of the production is lost due to Bemisia tabaci (Gennadius) B biotype attacks. Resistant plant germplasm can be an important method for controlling this pest in an integrated pest management program. This research aimed to evaluate the no-choice ovipositional preference of B. tabaci B biotype on 18 tomato genotypes with different densities and types of trichomes testing two screening techniques and to determine the influence of trichomes on whitefly ovipositional preference. Two methods of confinement experiments were used. Leaflets detached from the upper third part of the tomato plants (first experiment) and 30-day-old plants (second experiment) were infested with whiteflies during $24 \mathrm{~h}$. For the first experiment, simple linear correlation tests between the number of insects and eggs, and number of trichomes in the tomato genotypes were carried out. The first technique was better than the second one, as it was easier to carry out and the evaluation demanded less time and as well as was effective to discriminate the resistance level of the evaluated genotypes. Glandular trichomes had a negative correlation with attracted adults and number of eggs deposited, and a positive correlation with number of trapped insects. Negative correlations were observed between number of nonglandular trichomes and trapped insects, and also between total number of trichomes and attracted and trapped insects. Positive correlations were observed between number of total trichomes and eggs $\mathrm{cm}^{-2}$ and nonglandular trichomes and number of eggs. Both confinement methods efficiently discriminated whitefly oviposition among genotypes, especially the resistant ones. High levels of antixenosis for oviposition related to type IV glandular trichomes were exhibited by genotypes LA716, PI134417 and PI134418. The high level of ovipositional preference by B. tabaci for genotypes LA1963 and NAV1062 was related to a high density of type V nonglandular trichomes.
\end{abstract}

Key words: Solanum lycopersicum, plant resistance, whitefly, antixenosis, trichomes

\section{Não-preferência para oviposição de Bemisia tabaci (Gennadius) biótipo B em genótipos de tomateiro em teste sem chance de escolha}

RESUMO: O Brasil é um dos maiores produtores mundiais de tomate, porém grande parte da produção é perdida devido ao ataque de Bemisia tabaci (Gennadius) biótipo B. Entre as táticas de controle dessa praga num manejo integrado de pragas, pode-se relacionar a resistência de plantas. Avaliou-se a preferência para oviposição de $B$. tabaci biótipo $\mathrm{B}$ por 18 genótipos de tomateiro com diferentes densidades e tipos de tricomas utilizando-se dois métodos e estudou-se a influência dos tricomas nesta preferência, utilizando-se dois métodos para os experimentos de confinamento. Folíolos seccionados do terço superior dos tomateiros (primeiro método) e plantas com 30 dias de idade (segundo método) foram infestados com moscas-brancas durante $24 \mathrm{~h}$. Para o primeiro experimento, foram realizados testes de correlação linear simples entre o número de insetos e de ovos e o número de tricomas nos tomateiros. O primeiro método foi melhor que o segundo, pois foi mais fácil de ser conduzido e demandou menos tempo para as avaliações, além disso, foi efetivo em discriminar o nível de resistência dos genótipos avaliados. Tricomas glandulares correlacionaram-se negativamente com adultos atraídos e com ovos, e positivamente com adultos capturados. Correlações negativas ocorreram entre o número de tricomas não-glandulares e o número de insetos capturados, e entre o número de tricomas totais e o número de insetos atraídos e capturados. Correlações positivas ocorreram entre o número de tricomas totais e o número de ovos $\mathrm{cm}^{-2}$ e de tricomas nãoglandulares e o número de ovos. Ambos os métodos foram eficientes para discriminar os genótipos, principalmente os resistentes, com destaque para LA716, PI134417 e PI134418, que apresentaram altíssima antixenose para oviposição relacionada à presença de tricomas glandulares tipo IV. A preferência para oviposição de $B$. tabaci pelos genótipos LA1963 e NAV1062 está relacionada à alta densidade de tricomas não-glandulares tipo V. Palavras-chave: Solanum lycopersicum, resistência de plantas, mosca-branca, antixenose, tricomas

\section{Introduction}

Brazil produced around 3.35 million metric tons of tomato in 2007 and ranks as one of the major producers of this vegetable worldwide (Agrianual, 2009). Nearly $27 \%$ of the production is used in the processing industry and $73 \%$ for the fresh market (Gameiro et al., 2007). Nowadays, Bemisia tabaci (Gennadius) B biotype is one

Sci. Agric. (Piracicaba, Braz.), v.68, n.2, p.147-153, March/April 2011 
of the main pests for both industrial processing and for fresh market tomato. These interferes with the tomato production chain, which holds great economical and social importance in Brazil (Embrapa, 2006). In addition to direct damages caused by extracting large quantities of phloem sap, it also transmits plant viruses, with yield losses varying from 40 to $70 \%$ (Villas Bôas, 2005).

The improvement of germplasm aimed at the development of resistant genotypes to Bemisia spp. may be an important tool in integrated pest management of whiteflies (McAuslane et al., 1996). This can lessen use of insecticides, which are still widely used in whitefly control. Moreover, entomologists, plant breeders and related plant scientists are continuously in need of more accurate and more efficient techniques with which to assess the resistance or susceptibility of plant germplasm. New and improved insect infestation techniques and devices that safely and efficiently place test insects onto plants will also be essential to future progress of plant resistance to insects (Smith, 2000).

Many physiological and morphological characteristics have been correlated to the resistance of plants to the Bemisia species complex. Solanum lycopersicum (= Lycopersicon esculentum Mill) (Peralta et al., 2006) has eight trichomes types which vary by length, presence or absence of glandules in the apical extremity (Luckwill, 1943; Snyder and Carter, 1985; Channarayappa et al., 1992). These trichomes may interfere with oviposition, fixation and feeding of insects. LA716 (S. pennellii $=$ L. pennellii), PI134417 and PI134418 (S. habrochaites f. glabratum $=$ L. birsutum f. glabratum) had ovipositional nonpreference resistance to $B$. tabaci $\mathrm{B}$ biotype related to the presence of glandular trichomes, which can release allelochemicals (Toscano et al., 2002; Muigai et al., 2003; Fancelli et al., 2003, 2005). In S. pennellii, acylsugars are major components of the exudates produced by glandular trichomes (Burke et al., 1987; Fobes et al., 1985) and have been shown to reduce settling and oviposition of $B$. tabaci B biotype in a dosage-dependent fashion (Liedl et al., 1995). In $S$. habrochaites f. glabratum, the allelochemical 2-tridecanone had low levels of repellent and residual toxicity activity and the 2-undecanone had high levels of repellent and fumigant activity, and the ginger oil had high levels of repellent and residual toxicity activity on $B$. tabaci B biotype (Williams et al., 1980; Muigai et al., 2002). Additionally, whiteflies can be captured in exudates released by glandular trichomes (Freitas et al., 2002; Muigai et al., 2002; Fancelli et al., 2003).

The aim of this research was to evaluate the no-choice ovipositional nonpreference of B. tabaci B biotype on 18 tomato genotypes with different densities and types of trichomes testing two screening techniques and to determine the influence of trichomes on whitefly ovipositional preference.

\section{Material and Methods}

The experiments were carried out in a laboratory at a temperature of $23 \pm 2^{\circ} \mathrm{C}$, relative humidity of $70 \pm$
$10 \%$ and photophase of $13 \mathrm{~h}$. Evaluations were conducted with 18 tomato genotypes which were chosen based on differences concerning the densities and types of trichomes: cultivars Santa Clara and Fanny ( $S$. lycopersicum); VFNA (S. lycopersicum cerasiforme); LA716 (S. pennellii = L. pennellii); LA1963 (S. chilense = L. chilense); LA371, LA444-1 and LA462 (S. peruvianum = L. peruvianum); IAC237, LA722, LA1335, NAV1062, PI126931 and PI365928 (S. pimpinellifolium $=L$. pimpinellifolium); PI134417 and PI134418 (S. habrochaites f. glabratum $=$ L. birsutum f. glabratum); IAC294 (S. habrochaites) and IAC68F-22-2 (S. peruvianum $\times S$. lycopersicum). 'Santa Clara' was used as a susceptible control to B. tabaci B biotype while LA716, PI134417 and PI134418 were used as resistant controls, in a no-choice ovipositional preference assay.

For whitefly rearing, a colony was initiated from a population previously characterized as B. tabaci (B biotype). The insects were reared on soybean [Glycine $\max$ (L.) Merrill] and painted spurge (Euphorbia beterophylla L.) plants kept in a greenhouse with antiaphid screens.

Two methods were used to test for whitefly nonpreference. The first method used leaflets detached from the upper third part of the tomato plants and the second method used 30-day-old plants. For the first trial, seeds of tomato genotypes were germinated in plastic trays containing agricultural substrate. Fifteen days after sowing, the seedlings were transplanted into $3 \mathrm{~L}$ plastic pots containing a 3:1:1 mixture of soil, sand and organic compounds. The plants were fertilized with $1.5 \mathrm{~g}$ of simple superphosphate, $0.3 \mathrm{~g}$ of potassium chloride, $0.3 \mathrm{~g}$ of ammonium nitrate per kilo of soil, irrigated daily and kept in the greenhouse throughout the experiments. Ten plants (two per pot) represented each genotype.

For the first preference test, a transparent plastic cage (16 $\mathrm{cm}$ height and $13 \mathrm{~cm}$ diameter) was used. The cage had a plastic lid with a $6 \mathrm{~cm}$ diameter hole which was covered with an anti-aphid screen for airflow into the cage. A 5-cm-long plastic hose filled with distilled water was attached to a plastic holder in the inner wall of the cage where the tomato genotype leaflet was placed. Experimental insects were introduced in the cage through a hole on the side of the cage.

Totally expanded leaflets of 65 to 90 days old tomato representing different genotypes were collected from the upper third part of the plant. Three leaflets of the same leaf were used when needed, attempting to have a similar leaf area among the material evaluated. The leaflets were placed in plastic cages as described previously and infested with 25 males and 25 females during 24 hours. The number of attracted insects (settled on the leaflet after 24 hours) and the number of trapped insects by glandular trichomes per tomato leaflet were verified. The number of eggs found on the abaxial surface of each leaflet was recorded using a stereoscopic microscope. The leaf areas were measured using LI-COR (LI 3000A) and then the number of eggs per square centimeter was calculated. 
The number of glandular and nonglandular trichomes found on leaflets were counted and recorded, using a microscope (at a magnification of 100x), to correlate whitefly oviposition to trichomes density. For this procedure, semi-permanent glass slides of each leaflet were prepared using the epidermal fingerprint technique (Segatto et al., 2004). The number of glandular and nonglandular trichomes found on the abaxial surface in two areas of 3.5 $\mathrm{mm}^{2}$ of the leaflets, one proximal to the petiole (located close to the main vein, and between the second and the third vein), and far from the petiole was registered. Simple linear correlation tests between number of insects (attracted and trapped), number of eggs (leaflet and $\mathrm{cm}^{2}$ ), and number of trichomes (glandular, nonglandular and total) on the tomato genotypes leaflets were carried out.

For the second trial, 15 days after seeding, the seedlings were transplanted into $0.5 \mathrm{~L}$ plastic pots containing agricultural substrate (one seedling per pot), irrigated with nutritive solution $\left(1 \mathrm{M} \mathrm{KNO}_{3} 5 \mathrm{~mL} \mathrm{~L}^{-1} ; 1 \mathrm{M} \mathrm{KH}_{2} \mathrm{PO}_{4}\right.$ $1 \mathrm{~mL} \mathrm{~L}^{-1} ; 1 \mathrm{M} \mathrm{MgSO}_{4} 2 \mathrm{ml} \mathrm{L}^{-1}$; FeEDTA $1 \mathrm{~mL} \mathrm{~L}^{-1} ; 1 \mathrm{M}$ micronutrients $\left.1 \mathrm{~mL} \mathrm{~L}^{-1} ; 1 \mathrm{M} \mathrm{Ca}\left(\mathrm{NO}_{3}\right)_{2} 5 \mathrm{~mL} \mathrm{~L}^{-1}\right)$ (Sarruge, 1975) and maintained in a greenhouse until the plants were 30 days-old. Six plants (one per pot) represented each genotype. The same cages described in the first bioassay were used to infest these plants. However, the cages were placed in plastic pots containing 1-monthold tomato seedlings and held in place with the aid of 4 $\mathrm{cm}$ width masking tape. Each plant was infested by ten males and ten females' whiteflies during $24 \mathrm{~h}$. After this period, the adults were removed and the number of whitefly eggs found on the abaxial surface of three tomato leaflets per plant was observed and recorded for all genotypes in the experiment.

The trials were set up in a randomized block design with 30 replications for the first trial and six replications for the second trial, for each tomato genotype evaluated. The data were first analyzed through the test of homocedasticity by Bartlett (1937) and transformed as recommended. Then, the Bonferroni correction factor was applied and the data submitted to analysis of variance by the F-test and the means compared by Tukey test $(p \leq 0.05)$ using the SAS system 9.1 (SAS Institute, 2004).

\section{Results and Discussion}

Genotypes LA716, PI134417 and PI134418 were less attractive to $B$. tabaci B biotype for oviposition in both tests, either using leaflets detached from the upper third of tomato genotypes (first technique), or using 30-day-old plants infested (second technique) by whiteflies (Table 1).

Table 1 - Mean ( \pm SE) number of attracted and trapped adults and number of eggs laid by $B$. tabaci B biotype on 18 tomato genotypes, in two no-choice tests. Temperature: $23 \pm 2^{\circ} \mathrm{C}, \mathrm{RH}: 70 \pm 10 \%$, photophase: $13 \mathrm{~h}$.

\begin{tabular}{|c|c|c|c|c|c|}
\hline \multirow{3}{*}{ Genotype } & \multicolumn{5}{|c|}{ Detached leaflets plant } \\
\hline & \multicolumn{2}{|c|}{ Number of adults } & \multicolumn{2}{|c|}{ Number of eggs ${ }^{(1)}$} & \multirow{2}{*}{$\begin{array}{c}\text { Number of eggs per } \\
\text { leaflet }{ }^{(1)}\end{array}$} \\
\hline & Attracted $^{(1)}$ & Trapped $^{(2)}$ & Leaflet & $\mathrm{cm}^{2}$ & \\
\hline PI134417 & $25.0 \pm 1.6 \mathrm{a}$ & $6.4 \pm 1.4 \mathrm{~b}$ & $9.2 \pm 1.4 \mathrm{a}$ & $0.7 \pm 0.1 \mathrm{a}$ & $5.6 \pm 2.5 \mathrm{ab}$ \\
\hline PI134418 & $26.4 \pm 2.0 \mathrm{ab}$ & $4.2 \pm 0.9 \mathrm{c}$ & $15.5 \pm 2.5 \mathrm{a}$ & $1.2 \pm 0.2 \mathrm{ab}$ & $4.1 \pm 0.4 \mathrm{a}$ \\
\hline LA 1963 & $28.5 \pm 1.8 \mathrm{abc}$ & $0.0 \pm 0.0 \mathrm{c}$ & $60.1 \pm 6.5 \mathrm{bc}$ & $10.0 \pm 1.8 \mathrm{e}$ & $63.3 \pm 22.7 \mathrm{f}$ \\
\hline LA371 & $31.5 \pm 1.6 \mathrm{abcd}$ & $0.0 \pm 0.0 \mathrm{c}$ & $52.4 \pm 5.1 \mathrm{bc}$ & $5.4 \pm 0.6 \mathrm{~d}$ & $45.2 \pm 7.3 \mathrm{ded}$ \\
\hline Fanny & $32.4 \pm 1.3$ bcde & $0.0 \pm 0.0 \mathrm{c}$ & $75.1 \pm 6.6 \mathrm{~d}$ & $5.0 \pm 0.4 \mathrm{~cd}$ & $51.4 \pm 9.2 \mathrm{f}$ \\
\hline Santa Clara & $33.9 \pm 1.3 \mathrm{cde}$ & $0.0 \pm 0.0 \mathrm{c}$ & $50.8 \pm 5.5 \mathrm{bcd}$ & $2.2 \pm 0.2 \mathrm{abc}$ & $59.2 \pm 9.0 \mathrm{f}$ \\
\hline IAC 237 & $34.3 \pm 1.6 \mathrm{cde}$ & $0.1 \pm 0.1 \mathrm{c}$ & $58.3 \pm 5.6 \mathrm{~b}$ & $5.0 \pm 0.6 \mathrm{~d}$ & $34.2 \pm 3.4$ def \\
\hline PI365928 & $35.0 \pm 1.2 \mathrm{cde}$ & $0.0 \pm 0.0 \mathrm{c}$ & $54.6 \pm 7.2 \mathrm{~b}$ & $3.9 \pm 0.5 \mathrm{~cd}$ & $50.3 \pm 17.3 \mathrm{def}$ \\
\hline LA716 & $35.2 \pm 1.3 \mathrm{cde}$ & $31.0 \pm 1.5 \mathrm{a}$ & $1.0 \pm 0.6 \mathrm{a}$ & $0.1 \pm 0.1 \mathrm{a}$ & $6.7 \pm 1.8 \mathrm{ab}$ \\
\hline NAV1062 & $36.7 \pm 1.7 \mathrm{de}$ & $0.0 \pm 0.0 \mathrm{c}$ & $76.3 \pm 6.6 \mathrm{bcd}$ & $6.0 \pm 0.6 \mathrm{~d}$ & $47.7 \pm 7.6 \mathrm{def}$ \\
\hline PI126931 & $36.8 \pm 1.2 \mathrm{de}$ & $0.0 \pm 0.0 \mathrm{c}$ & $66.2 \pm 6.5 \mathrm{bcd}$ & $4.8 \pm 0.5 \mathrm{~d}$ & $20.6 \pm 2.8$ bcde \\
\hline LA444-1 & $36.8 \pm 1.2 \mathrm{de}$ & $0.7 \pm 0.6 \mathrm{c}$ & $55.9 \pm 7.4 \mathrm{~b}$ & $5.7 \pm 1.0 \mathrm{~d}$ & $14.8 \pm 2.3 \mathrm{abc}$ \\
\hline LA 462 & $36.9 \pm 1.8 \mathrm{de}$ & $0.0 \pm 0.0 \mathrm{c}$ & $73.2 \pm 7.8 \mathrm{bcd}$ & $5.9 \pm 0.7 \mathrm{~d}$ & $40.6 \pm 5.5 \mathrm{def}$ \\
\hline LA 722 & $38.1 \pm 1.4 \mathrm{de}$ & $0.0 \pm 0.0 \mathrm{c}$ & $75.3 \pm 7.0 \mathrm{bcd}$ & $5.5 \pm 0.4 \mathrm{~d}$ & $42.9 \pm 4.3 \mathrm{def}$ \\
\hline IAC 294 & $38.1 \pm 1.4 \mathrm{de}$ & $0.0 \pm 0.0 \mathrm{c}$ & $40.8 \pm 4.8 \mathrm{~b}$ & $2.3 \pm 0.3 \mathrm{abc}$ & $18.6 \pm 2.7 \mathrm{bcd}$ \\
\hline IAC 68-F-22-2 & $38.4 \pm 1.3 \mathrm{de}$ & $0.0 \pm 0.0 \mathrm{c}$ & $57.0 \pm 5.2 \mathrm{bcd}$ & $3.7 \pm 0.4 \mathrm{bcd}$ & $63.2 \pm 5.9 \mathrm{f}$ \\
\hline VFNA & $38.9 \pm 1.3 \mathrm{de}$ & $0.0 \pm 0.0 \mathrm{c}$ & $72.2 \pm 6.2 \mathrm{~cd}$ & $4.2 \pm 0.4 \mathrm{~cd}$ & $49.8 \pm 10.1$ ef \\
\hline LA1335 & $40.4 \pm 1.7 \mathrm{e}$ & $0.0 \pm 0.0 \mathrm{c}$ & $60.8 \pm 7.8 \mathrm{bc}$ & $4.3 \pm 0.6 \mathrm{~cd}$ & $43.3 \pm 15.6 \mathrm{cdef}$ \\
\hline $\mathrm{F}$ & $9.21 *$ & $187.66^{*}$ & $30.51 *$ & $21.13^{*}$ & $16.55^{*}$ \\
\hline $\mathrm{CV} \%$ & 5.38 & 18.86 & 13.43 & 21.78 & 8.66 \\
\hline
\end{tabular}

Means followed by the same letters within columns are not different (Tukey test, $p \leq 0.05)$; ${ }^{(1)}$ Original data; transformed in log $(\mathrm{x}+$ 10) for analysis; ${ }^{(2)}$ Original data; transformed in $(x+3)^{1 / 2}$ for analysis. 
Both experiments were effective in discriminating especially the resistant genotypes. There was, however, variation in the classification of the susceptible genotypes depending on the method used to confine the insects in the oviposition substrate. As a whole, 'Fanny', LA1963, IAC68F-22-2 and 'Santa Clara' genotypes were the most preferred ones for oviposition by $B$. tabaci B biotype. The first technique is better instead of the second one, as it is easier to carry out and the evaluation demands less time, which is important when the screening test involves too many genotypes. Besides, the technique was effective to discriminate the resistance level of the evaluated genotypes. In addition, more accurate and more efficient techniques are continuously in need to assess the resistance or susceptibility of plant germplasm (Smith, 2000).

Other authors have also reported that genotype LA716 was the least attractive and showed the lowest oviposition rate by B. tabaci B biotype while 'Santa Clara' was the most attractive and received the highest level of oviposition (Toscano et al., 2002; Baldin et al., 2005). Nevertheless, Fancelli et al. (2003) and Lima et al. (2005) have suggested that 'Santa Clara' has moderate ovipositional nonpreference resistance to whiteflies. Fancelli et al. (2003) have also observed that NAV1062 was preferred for oviposition by $B$. tabaci B biotype in five evaluations carried out in tomato genotypes.

Samples of the trichomes in the tomato genotypes were only taken in the confinement test where leaves were detached from the upper third part of the tomato plants. The samples, however, showed that the number of trichomes found on the leaves increased as the plant aged, since this test was carried out when the tomato plants were between 65 to 90 days old (Figure 1). This test was carried out during the winter, from July to August 2008, and there were delays of at least 20 days in the development of the plants. Therefore, 65-day-old plants had the size of 45-dayold plants. It is noteworthy that 66 to 70 -day-old tomato genotypes had lower density of total trichomes and 81 to 90-day-old plants had the highest density of total trichomes

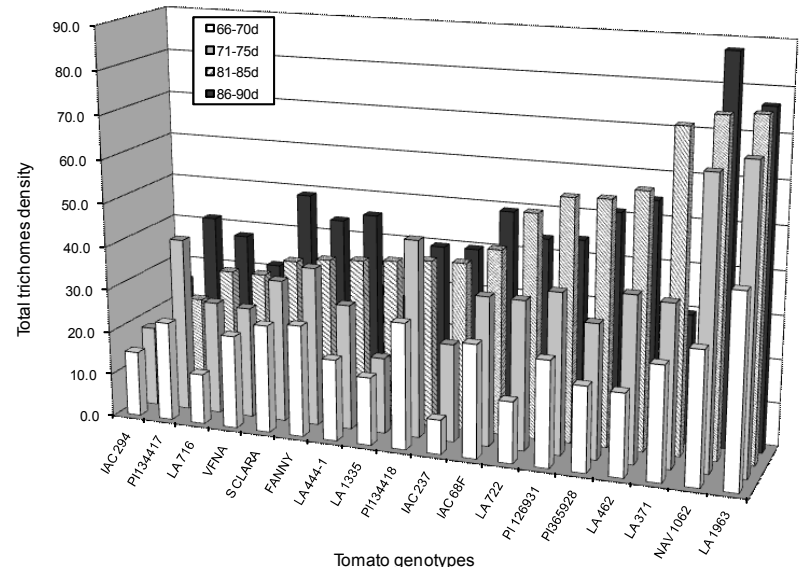

Figure 1 - Density of total trichomes on 18 tomato genotypes with 66 to 90 days-old.
(Figure 1). Then, as the plant ages, an increase in the total trichomes density in tomato genotypes occurs.

The increase in the number of glandular trichomes as the plant aged was only observed for genotypes with high densities of these trichomes. Among them are PI134418, PI134417, LA716 and IAC294 (Figure 2). For the other genotypes, the density of the glandular trichomes was somewhat constant. In S. lycopersicum, Luckwill (1943) identified seven trichome types that were labeled consecutively I-VII. This classification was based on length, and presence or absence of glandules in the apical extremity. The nonglandular trichomes (II, III and V) are highly similar among themselves, differing only in length; of these, the type $\mathrm{V}$ is the shortest nonglandular trichome and the most common in tomato leaves. The glandular trichomes (I, IV, VI and VII) have 'heads' that release alellochemicals; of these, only type VI and type VII have multicellular tips (Snyder and Carter, 1985; Channarayappa et al., 1992; Simmons and Gurr, 2005). Lately, because of the greater diversity of trichomes found on the leaf surface, some trichomes were subdivided: type $\mathrm{V}(\mathrm{Va}, \mathrm{Vb}$ and $\mathrm{Vc})$ and type VI (VIa, VIb and VIc); and a new type (VIII) was characterized (Channarayappa et al., 1992).

Significant correlations were observed $(p \leq 0.05)$ between total trichomes density and number of attracted insects $(r=-0.22)$, number of trapped insects $(r=-0.10)$ and number of eggs $\mathrm{cm}^{-2}(\mathrm{r}=0.20)$; and between nonglandular trichomes density and number of trapped insects $(r=-0.36)$, number of eggs per leaflet $(r=0.16)$ and number of eggs $\mathrm{cm}^{-2}(\mathrm{r}=0.35)$ (Table 2). The genotypes with the greatest density of total and nonglandular trichomes were LA1963 (S. chilense), NAV1062 (S. pimpinellifolium), LA371 (S. peruvianum) (Table 3). They had mainly type $\mathrm{V}$ nonglandular trichomes, which was not subdivided in this research as suggested by Channarayappa et al. (1992). In addition to type V nonglandular trichomes, these genotypes also had a low density of type VIa glandular trichomes.

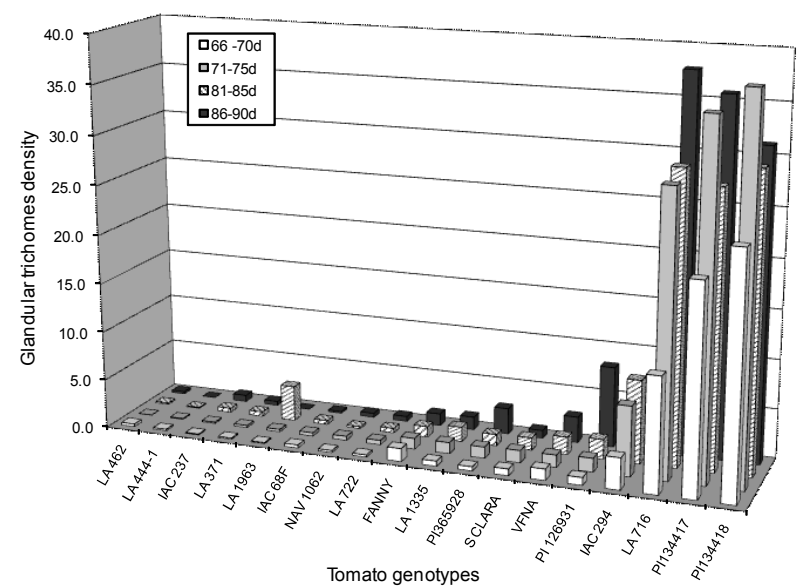

Figure 2 - Density of glandular trichomes on 18 tomato genotypes with 66 to 90 days-old. 
Table 2 - Correlation coefficients between the number of insects and number of eggs laid by $B$. tabaci $\mathrm{B}$ biotype and the density of trichomes on 18 tomato genotypes, in a no-choice test. Temperature: $23 \pm 2^{\circ} \mathrm{C}, \mathrm{RH}: 70 \pm 10 \%$, photophase: $13 \mathrm{~h}$.

\begin{tabular}{llcc}
\hline \multirow{2}{*}{ Parameter } & & Number of trichomes $\mathrm{mm}^{-2}$ & Glandular \\
\cline { 2 - 4 } & Total & Nonglandular & $-0.29^{*}$ \\
\hline Number of adults & & $-0.05^{\mathrm{NS}}$ & $0.55^{*}$ \\
Attracted & $-0.22^{*}$ & $-0.36^{*}$ & \\
Trapped & $-0.10^{*}$ & & $-0.43^{*}$ \\
Leamber of eggs & & $0.16^{*}$ & $-0.35^{*}$ \\
$\mathrm{~cm}^{2}$ & $-0.05^{\mathrm{NS}}$ & $0.35^{*}$ & \\
\hline
\end{tabular}

Significant correlation by t-test $(p \leq 0.05)$.

Table 3 - Mean ( \pm SE) number of trichomes $\mathrm{mm}^{-2}$ on abaxial surface of 18 tomato genotypes.

\begin{tabular}{|c|c|c|c|}
\hline Genotype & Total $^{(1)}$ & Nonglandular ${ }^{(1)}$ & Glandular $^{(2)}$ \\
\hline LA1963 & $63.7 \pm 5.4 \mathrm{a}$ & $62.8 \pm 5.4 \mathrm{a}$ & $0.9 \pm 0.5 \mathrm{de}$ \\
\hline NAV1062 & $59.5 \pm 4.1 \mathrm{ab}$ & $59.2 \pm 4.1 \mathrm{ab}$ & $0.3 \pm 0.0 \mathrm{de}$ \\
\hline LA371 & $41.4 \pm 4.4 \mathrm{bc}$ & $41.1 \pm 4.4 \mathrm{abc}$ & $0.3 \pm 0.1 \mathrm{de}$ \\
\hline LA462 & $38.7 \pm 2.8 \mathrm{bc}$ & $38.5 \pm 3.8 \mathrm{bc}$ & $0.2 \pm 0.0 \mathrm{e}$ \\
\hline PI126931 & $38.2 \pm 2.7 \mathrm{abc}$ & $36.9 \pm 2.6 \mathrm{bc}$ & $1.4 \pm 0.2 \mathrm{~d}$ \\
\hline PI134418 & $38.0 \pm 2.6 \mathrm{bc}$ & $8.0 \pm 1.0 \mathrm{ef}$ & $30.0 \pm 2.1 \mathrm{a}$ \\
\hline PI365928 & $35.3 \pm 3.4 \mathrm{~cd}$ & $34.3 \pm 3.4 \mathrm{~cd}$ & $1.0 \pm 0.2 \mathrm{de}$ \\
\hline IAC 68-F-22-2 & $35.2 \pm 2.1 \mathrm{c}$ & $34.9 \pm 2.1 \mathrm{bc}$ & $0.3 \pm 0.0 \mathrm{de}$ \\
\hline Fanny & $34.1 \pm 2.5 \mathrm{~cd}$ & $32.9 \pm 2.1 \mathrm{~cd}$ & $1.2 \pm 0.2 \mathrm{de}$ \\
\hline PI134417 & $33.5 \pm 2.0 \mathrm{~cd}$ & $4.7 \pm 0.7 \mathrm{f}$ & $28.8 \pm 1.5 \mathrm{a}$ \\
\hline LA722 & $33.2 \pm 3.0 \mathrm{~cd}$ & $32.8 \pm 3.3 \mathrm{~cd}$ & $0.3 \pm 0.1 \mathrm{de}$ \\
\hline Santa Clara & $32.7 \pm 4.1 \mathrm{cde}$ & $31.7 \pm 4.1 \mathrm{~cd}$ & $1.0 \pm 0.1 \mathrm{de}$ \\
\hline LA444-1 & $29.4 \pm 2.3 \mathrm{cde}$ & $29.3 \pm 2.3 \mathrm{~cd}$ & $0.1 \pm 0.0 \mathrm{e}$ \\
\hline VFNA & $26.4 \pm 1.9 \mathrm{cde}$ & $24.9 \pm 1.9 \mathrm{~cd}$ & $1.5 \pm 0.2 \mathrm{de}$ \\
\hline LA 716 & $24.2 \pm 2.1 \mathrm{cde}$ & $0.0 \pm 0.0 \mathrm{~g}$ & $24.2 \pm 2.1 \mathrm{~b}$ \\
\hline IAC 237 & $23.7 \pm 2.6 \mathrm{de}$ & $23.4 \pm 2.6 \mathrm{~d}$ & $0.3 \pm 0.1 \mathrm{e}$ \\
\hline LA 1335 & $22.6 \pm 2.3 \mathrm{de}$ & $21.6 \pm 2.2 \mathrm{~d}$ & $1.0 \pm 0.2 \mathrm{de}$ \\
\hline IAC 294 & $18.4 \pm 1.9 \mathrm{e}$ & $12.1 \pm 1.8 \mathrm{e}$ & $6.3 \pm 1.1 \mathrm{c}$ \\
\hline $\mathrm{F}$ & $11.11^{*}$ & $226.69^{*}$ & $66.33^{*}$ \\
\hline $\mathrm{CV} \%$ & 10 & 29 & 11 \\
\hline
\end{tabular}

Means followed by the same letters within columns are not different (Tukey test, $p \leq 0.05) .{ }^{1}$ Original data; transformed in log ( $\left.\mathrm{x}+10\right)$ for analysis. ${ }^{2}$ Original data; transformed in $(\mathrm{x}+3)^{1 / 2}$ for analysis.

On the whole, few type II and type III nonglandular trichomes were found in the evaluated areas in all tested genotypes, and no type VIII nonglandular trichome and type VIb glandular trichome were recognized. Therefore, because the nonglandular and total trichomes density correlated positively with the number of eggs, except for number of eggs per leaflet (Table 2), this suggests that the high density of type $\mathrm{V}$ trichomes found in LA1963 (S. chilense) and NAV1062 (S. pimpinellifollium) promoted a higher level of oviposition of B. tabaci B biotype in both genotypes studied (Table 1). Other researchers have also reported that the high density of trichomes in tomato cultivars (especially type $\mathrm{V}$ nonglandular tri- chomes) is positively correlated with the oviposition of B. tabaci B biotype (Heinz and Zalom, 1995; Snyder et al., 1998; Toscano et al., 2002). However, Heinz and Zalom (1995) did not find significant correlations between total trichomes density and the oviposition of whitefly in several wild tomato genotypes ( $S$. chilense, $S$. chmielewskii, S. habrochaites, S. pennellii, S. peruvianum, S. pimpinellifollium and S. neorickii). Moreover, Muigai et al. (2003) suggested that the total trichomes density is not a reliable criterion in the selection of features related to the resistance to $B$. tabaci B biotype.

Significant correlations were noted $(p \leq 0.05)$ between glandular trichomes density and the number of attracted 
insects $(r=-0.29)$, number of trapped insects $(r=0.55)$, number of eggs per leaflet $(\mathrm{r}=-0.43)$ and number of eggs $\mathrm{cm}^{-2}(\mathrm{r}=-0.35)$ (Table 2$)$. Thus, the genotypes that presented higher density of glandular trichomes, PI134417 and PI134418 (Table 3), attracted, consequently, a smaller number of whiteflies (25.0 and 26.4, respectively - Table 1$)$. Such genotypes, along with LA716, resulted in the lowest oviposition rates (9.2, 15.5 and 1.0 eggs per leaflet and $0.7,1.2$ and 0.1 eggs $\mathrm{cm}^{-2}$, respectively). The high incidence of glandular trichomes in LA716, PI134417 and PI134418 also promoted higher number of trapped whiteflies (31.0, 6.4 and 4.2 , respectively) (Table 1 ).

Genotype LA716 (S. pennellii) had only type IV glandular trichomes. This finding was also noted by Toscano et al. (2001, 2002). Genotypes PI134417 and PI134418 (S. habrochaites f. glabratum) also had a high density of type IV glandular trichomes, and a low density of types I, VIc and VII glandular trichomes, and type $\mathrm{V}$ nonglandular trichomes. Also, Channarayappa et al. (1992) have suggested that the trichome type VIc found on $S$. habrochaites is associated with a physical resistance to whitefly infestation and proliferation and would be helpful in prevention of the spread of viruses.

The data suggest that the high resistance of LA716 (S. pennellii) is related to the presence of type IV glandular trichomes, in accordance to Williams et al. (1980). Such trichomes grant to the genotype, the ovipositional nonpreference resistance to B. tabaci B biotype. This observation was also observed by Toscano et al., 2002; Fancelli et al., 2003; Muigai et al., 2003. However, when the exudate found in the trichomes was removed from LA716, Fancelli et al. (2005) noted an increase in the number of eggs of $B$. tabaci B biotype, indicating a correlation between exudate and antixenosis for oviposition. Such results have not been noted for PI134417, which probably indicates that its antixenosis resistance in relation to whiteflies must be related to other factors (Fancelli and Vendramim, 2002; Fancelli et al., 2005).

The resistance of $S$. pennellii (LA716) is related to antixenosis for oviposition, mediated by acylsugars present in type IV glandular trichomes exudates (Barten et al., 1994; Muigai et al., 2003; Fancelli et al., 2005; Silva et al., 2008). In addition to causing oviposition nonpreference, whiteflies may be captured by exudates released by glandular trichomes (Toscano et al., 2001; Freitas et al., 2002; Muigai et al., 2002; Fancelli et al., 2003, 2008), an observation also noticed in this research. However, such allelochemical does not affect the development of whitefly nymphs (Liedl et al., 1995), supporting therefore that this allelochemical confers antixenosis for oviposition in tomato genotypes.

Future improvements in tomato cultivars should be made with consideration of genotypes that have type IV glandular genotypes, which are found in high densities in $S$. pennellii, S. habrochaites and $S$. habrochaites $\mathrm{f}$. glabratum. Because these trichomes decrease the attractiveness and contribute to ovipositional nonpreference, an additional benefit may be obtained by these resistant genotypes if they also reduce problems related to the transmission of viruses through $B$. tabaci.

\section{Acknowledgements}

To Conselho Nacional de Desenvolvimento Científico e Tecnológico (CNPq), to Fundação de Amparo à Pesquisa do Estado de São Paulo (FAPESP) for a research fellowship and to Dr. Francisco Antônio Monteiro from the Soil Science Department (ESALQ/ USP) who provided the nutritive solutions.

\section{References}

Agrianual. 2009. Consulting and Commerce. Tomato. Annual of Brazilian agriculture. p. 472-478. FNP, São Paulo, SP, Brazil. (in Portuguese).

Baldin, E.L.L.; Vendramim, J.D.; Lourenção, A.L. 2005. Resistance of tomato genotypes to the whitefly Bemisia tabaci (Gennadius) biotype B (Hemiptera: Aleyrodidae). Neotropical Entomology 34: 435-441. (in Portuguese, with abstract in English).

Barten, J.H.M.; Thome, C.H.; Stevens, M.R.; Schuster, D.J.; Scott, J.W.; Chambliss, O.L. 1994. Evaluating resistance in tomato to the silverleaf whitefly, Bemisia argentifolii. Phytoparasitica 22: 330-331.

Bartlett, M.S. 1937. Properties of sufficiency and statistical tests. Proceedings of the Royal Statistical Society Series A 160: 268282.

Burke, B.A.; Goldsby, G.; Mudd, J.B. 1987. Polar epicuticular lipids of Lycopersicon pennellii. Phytochemistry 26: 2567-2571.

Channarayappa, S.G.; Muniyappa, V.; Frist, R.H. 1992. Resistance of Lycopersicon species to Bemisia tabaci, a tomato leaf curl virus vetor. Canadian Journal of Botany 70: 2184-2192.

Empresa Brasileira de Pesquisa Agropecuária [EMBRAPA]. Centro Nacional de Pesquisas de Hortaliças. 2006. Tomato cropping for industrialization. Available at: www.cnph.embrapa.br/ paginas/sistemas_producao/cultivo_tomate_industrializacao.htm. [Accessed Sep. 28, 2009]. (in Portuguese).

Fancelli, M.; Vendramim, J.D. 2002. Development of Bemisia tabaci (Gennadius, 1889) biotype B on Lycopersicon spp. genotypes. Scientia Agricola 59: 665-669.

Fancelli, M.; Vendramim, J.D.; Lourenção, A.L.; Dias, C.T.S. 2003. Attractiveness and oviposition preference of Bemisia tabaci (Gennadius) (Hemiptera: Aleyrodidae) biotype B in tomato genotypes. Neotropical Entomology 32: 319-328. (in Portuguese, with abstract in English).

Fancelli, M.; Vendramim, J.D.; Friguetto, R.T.S.; Lourenção, A.L. 2005. Glandular exudate of tomato genotypes and development of Bemisia tabaci (Genn.) (Sternorryncha: Aleyrodidae) biotype B. Neotropical Entomology 34: 659-665. (in Portuguese, with abstract in English).

Fancelli, M.; Vendramim, J.D.; Lourenção, A.L. 2008. Oviposition and nymphal dispersion of Bemisia tabaci biotype B on tomato genotypes. Bragantia 67: 933-939 (in Portuguese, with abstract in English).

Fobes, J.F.; Mudd, J.; Marsden, M. 1985. Epicuticular lipid on the leaves of L. pennellii and L.esculentum. Plant Physiology 77: 567570.

Freitas, J.A; Nonato, M.F.B.; Souza, V.S.; Maluf, W.R.; Ciociola Jr., A.I.; Leite, G.L.D. 2002. Relationship between acylsugars, glandular trichome and resistance of tomato plants to the silverleaf whitefly. Acta Scientiarum 24: 1313-1316. (in Portuguese, with abstract in English).

Gameiro, A.H.; Caixeta Filho, J.V.; Rocco, C.D.; Rangel, R. 2007. Loss estimation in the provision of tomato industrial processing in Goias State. Informações Econômicas 37: 7-16. (in Portuguese). 
Heinz, K.M.; Zalom, F.G. 1995. Variation in trichome-based resistance to Bemisia argentifolii (Homoptera, Aleyrodidae) oviposition on tomato. Journal of Economic Entomology 88: 1494-1502.

Liedl, B.E.; Lawson, D.M.; White, K.K.; Shapiro, J.A.; Cohen, D.E.; Carson, W.C.; Trumble, J.T.; Mutschler, M.A. 1995. Acylsugars of wild tomato Lycopersicon pennellii alters settling and reduces oviposition of Bemisia argentifolii (Homoptera, Aleyrodidae). Journal of Economic Entomology 88: 742-748.

Lima, A.N.; Batista, J.L.; Costa, N.P. 2005. Varieties effects on whitefly (Bemisia tabaci L.) of tomato tree cultivation. Caatinga 18: 92-97. (in Portuguese, with abstract in English).

Luckwill, L.L.C. 1943. The genus Lycopersicon. An historical, biological, and taxonomic survey of the wild and cultivated tomatoes. Aberdeen University Press, Aberdeen, UK. (University Studies, 120).

McAuslane, H.J. 1996. Influence of leaf pubescence on ovipositional preference of Bemisia argentifolii (Homoptera, Aleyrodidae) on soybean. Environmental Entomology 25: 834-841.

Muigai, S.G.; Bassett, M.J.; Schuster, D.J.; Scott, J.W. 2003. Greenhouse and field screening of wild Lycopersicon germplasm for resistance to the whitefly Bemisia argentifolii. Phytoparasitica 31: $1-12$.

Muigai, S.G.; Schuster, D.J.; Bassett, M.J.; Scott. J.W.; McAuslane, H.J. 2002. Mechanisms of resistance in Lycopersicon germplasm to the whitefly Bemisia argentifolii. Phytoparasitica 30: 347-360.

Peralta, I.E.; Knapp, S.; Spooner, D.M. 2006. Nomenclature for wild and cultivated tomatoes. Report of the Tomato Genetics Cooperative 56: 6-12.

Sarruge, J.R. 1975. Nutritive solution. Summa Phytopathologica 1: 231-233. (in Portuguese, with abstract in English).

SAS Institute. 2004. SAS system 9.1. SAS Institute, Cary, NC, USA.

Segatto, F.B.; Bisognin, D.A.; Benedetti, M.; Costa, L.C.; Rampelotto, M.V.; Nicoloso, F.T. 2004. A technique for the anatomical study of potato leaf epidermis. Ciência Rural 34: 1597-1601. (in Portuguese, with abstract in English).
Silva, V.F.; Cardoso, M.G.; Moraes, J.C.; Pimentel, F.A.; Gonçalves, L.D.; Neri, D.K.P. 2008. Characterization and evaluation of synthetic acylsugar on the behavior of the whitefly Bemisia tabaci (Gennadius, 1886) b biotype (Hemiptera: Aleyrodidae) in tomato plant. Ciência Agrotécnica 32: 1408-1412. (in Portuguese, with abstract in English).

Simmons, A.T.; Gurr, G.M. 2005. Trichomes of Lycopersicon species and their hybrids: effects on pest and natural enemies. Agricultural and Forest Entomology 7: 265-276.

Smith, C.M. 2000. Plant resistance to insects. p. 171-208. In: Rechcigl, J.E.; Rechcigl, N.A., eds. Biological and biotechnological control of insect pests. CRC Press, Boca Raton, FL, USA.

Snyder, J.C.; Carter, C.D. 1985. Trichomes on leaves of Lycopersicon birsutum, L. esculentum and their hybrids. Euphytica 34: 53-64.

Snyder, J.C.; Simmons, A.M.; Tracker, R.R. 1998. Attractancy and ovipositional response of adult Bemisia argentifolii (Homoptera: Aleyrodidae) to type IV trichome density on leaves of Lycopersicon hirsutum grown in three daylength regimes. Journal of Entomological Science 33: 270-281.

Toscano, L.C.; Boiça Júnior, A.L.; Santos, J.M.; Almeida, J.B.S.A. 2001. Types of trichomes in Lycopersicon genotypes. Horticultura Brasileira 19: 204-206. (in Portuguese, with abstract in English).

Toscano, L.C.; Boiça Júnior, A.L.; Maruyama, W.I. 2002. Nonpreference of whitefly for oviposition in tomato genotypes. Scientia Agricola 59: 677-681.

Villas Bôas, G.L. 2005. Integrated management of whitefly. Available at: www.cnph.embrapa.br/paginas/publicacoes/ publicacoes_2005/pdf_vfinal_2005/Comunicado\%20Tec-30.pdf. [Accessed Sep. 30, 2009]. (in Portuguese).

Williams, W.G.; Kennedy, G.G.; Yamamoto, R.T.; Thacker, J.D.; Bordner, J. 1980. 2-Tridecanone: a naturally occurring insecticide from wild tomato, Lycopersicum hirsutum f. glabratum. Science 207: 188-189.

Received November 13, 2009

Accepted August 17, 2010 